\title{
THE SHELL
}

Christianne Balk

This evening, down

By the river road

I found a shell,

A cicada dead.

His eyes were coral,

And frozen wide,

Bright orange eyes

Stared right at me.

I picked him up,

So the insect sat

Poised on my palm,

As if alive

With olive armour

Hard as bone-

But he was light,

Light as a leaf.

His amber wings

Had two brown spots

Like leaded glass

Stained by smoke.

All black and green

The insect sat

All green with a black

Mask on his face.

And because of the mask

He seemed like one

Who hid his head,

A creature grown old,

Never tired of disguise.

And because of the moon

He seemed to glow

With phosphor inside. 